\title{
To Bill Buckner on His Release by the Boston Red Sox
}

The papers total your career

in easy symmetry: 2,542

big league hits and one

stupendous World Series whiff.

Fate's a bad hop, Billy Buck, or no hop at all. We had to watch nothing change on the TV replay. You were playing Mookie perfectly though I bet some nights sleep would come easier if you'd been hopelessly out of range.

Okay, maybe Stanley wouldn't have gotten to the bag in time.

Knowing this you know nothing except what makes a life look back.

One stupid grounder (that replay in the mind) enough to justify ten thousand coaches shouting ten million times: Eye on the ball! How many times can you wrap your ankles in ice and Ace bandages and lace those ridiculous high-tops to your rickety shins? In a week, Buck,

I'm forty, and you're a lousy reminder of how young thirty-seven is.

Sure, you can still get around on a fastball, foul off junk from the corners and slap any fat-hanging curve into the gap. But even designated hitters have to get down the line, Buck.

You're a jalopy with bad wheels.

You're the only ballplayer I ever saw run with his arms. I remember 
how you scored from second in the fifth game on Dewey's hit and made it look incredibly difficult - windmilling around third, bowlegged and flatfooted, shimmying till you flopped and skidded home.

NBC loved it and so did we each time the replay took forever. But that was before the ground ball and the blank ending, early winter and its unredeeming spring, and now getting cut midseason, a thing they call release.

\section{ETHERIDGE}

July. Port Townsend. Early afternoon and already you were pathetic, fingers around the neck of a brown sack under the trees, words botched and rambling. And that evening, after we'd waited so long in the dark of the theater for the only black man in town, when you came on stage, brushed aside the mike and opened your throat to Willow, Weep for $M e$, slow and deep, waveringI cringed. But then you turned to poemsbelly songs made up in the joint, about Slick and Hard Rock and Malcolm and Mr. K the Love of My Life, and said them by heart in perfect pitch, never missing a syllable.

Next morning, catching you weaving across the grass, as barn swallows flew sheer in the sun, I thought perhaps you'd climb into the light again to sing. 